\title{
Visual Communication as A Medium Sending Standard Operating Procedure (Sop) Message to Public During Pandemic Covid-19
}

\author{
Hanafi Mohd Tahir ${ }^{1, *}$ Nagib Padil ${ }^{2,}$ Mohd Shahril Abd Rashid ${ }^{3,}$ \\ Shahrel Nizar Baharom ${ }^{4}$, Dalila Kamarudin ${ }^{5}$, \\ 1,2,3,4 Faculty of Art and Design, Universiti Teknologi MARA, Perak Branch, Seri Iskandar Campus Malaysia. \\ ${ }^{5}$ Percetakan Nasional Berhad, Malaysia \\ * Corresponding author: Email: hanaf185@uitm.edu.my
}

\begin{abstract}
This concept paper discusses the importance and capability, implementing visual communication in the Standard Operating Procedure (SOP). As the whole country faced with Covid-19, visual communications became widely used method delivering information. Social media usage was increasing in digital and online activities because of demand getting information for Covid-19. Visual communication helps identify instructions, guidance and actions that need to be done for Covid-19. A lot of information in the form of graphics is designed as visual communication and aimed at achieving the objectives of explaining, educating and facilitating understanding to the public. To be aware of how visual communication functions, a communication model was chosen as a model for discussion in this paper. It's involves five component ways of communication: who said it, what was said, in what channel it was said, to whom it was said and with what effect it was said.
\end{abstract}

Keywords: Communication, Visual communication, Role of visual communication, Social media, Pandemic covid-19.

\section{INTRODUCTON}

Year of 2020 become a history and challenging year for people all over the world. All places in the world were awakened with terrifying disease, Corona Virus and it is well known as Covid-19. Malaysia also no exception affected by this terrifying pandemic. Covid-19 disease was found in Malaysia early of year 2020 and all Malaysian was shocked, confused, worried and in a panic situation. It is a new situation that affects all communities daily life activities. Chronology on pandemic Covid-19 (2019-nCov) as addressed by [2] started when three of Chinese citizens came to Malaysia. It is the first case of Covid-19 reported in Malaysia. They were identified, entering Malaysia on 23rd January 2020. Since after that, the disease has spread quickly and trigger the pandemic Covid-19 in Malaysia.

Almost every day, sudden death news of patients Covid-19 becomes a terrifying news around the world. Due to less knowledge and an unprepared situation, this disease triggers a panic situation among Malaysian.
Statistics number of death and quick spreading of Covid19 increase from time to time and forcing the government to enforce an action called Movement Control Order (MCO). During the enforcement, everybody is waiting for current news of pandemic Covid-19. The need to obtain information on health situations becomes the most important issues to everyone every day. Across the world to communicate, electronic media is used as a communication platform almost entirely and comprehensively by all levels of communities in Malaysia. Internet, Facebook, Instagram, Tweeter, WhatsApp and Telegram are among the 'popular' communication platforms used as well as information obtained via radio and television.

The Malaysia Ministry of Health $(\mathrm{MOH})$ as well as the Malaysia National Security Council (NSC) began to publicise guidelines for the public on how to curb, treat and control the Covid-19 disease. This action could prevent a panic atmosphere among communities. Several SOPs were introduced and implemented to control the disease of Covid-19. Visual communication began to 
play an important role in the implementation of the SOP recommended by the government. Each community's activity and daily movement begins with the SOP set.

During most of country struggling and faced with the pandemic Covid-19, visual communication became such a great method and widely used in delivering information. Visual communication has helped communities to identify the instructions, guidance and actions that need to be carried out for the control and transmission of Covid-19 disease. Many graphic info about Covid-19 are designed and produced as visual communications aimed at achieving explaining objectives, educating and facilitating understanding. The importance of the public understanding visual communication is crucial so that the actual information presented can be achieved. The importance of visual literacy for teaching and learning so that understanding of visuals can be achieved properly [9].

\section{CONNECTION BETWEEN VISUAL COMMUNICATION AND COMMUNICATION MODELS}

Communication models are a systematic representation process which helps communities to understand the way of communication works been done. Visual communication refers to the way of communication through visual presentations. Model of communication was developed to form a general perspective of communication. Due to the model's communication, it will help to break a complex issue of communication with a simple communication solution.

Visual communication is a complex process and it is difficult to determine what aspects of a communication issues will encounter. To aware of how visual communication functions, communication model of Harold D. Lasswell was chosen as a model of discussion for this paper. Harold Lasswell is a communication theorist and developed this communication model in 1948. It is called ' $5 \mathrm{~W}$ Model' and an earlier model and the most influential communication models. Lasswell's communication model had developed five component way of communication who said it, what was said, in what channel it was said, to whom it was said and with what effect it was said [11].

The first component is 'Who said it', refer to the communicator, the sender that spreads messages to target audience. Visual is the communicator that delivers information, guidelines and SOP of Covid-19 disease. All visual information and messages of Covid-19 would create an awareness and prevention of the dangerous disease among all Malaysian. Figure 1 shows an infographic of visual communication from $\mathrm{MOH}$ describing the statistics abroad and locally of Covid-19 disease. This message would create an awareness and prevention of the dangerous disease among all Malaysian.

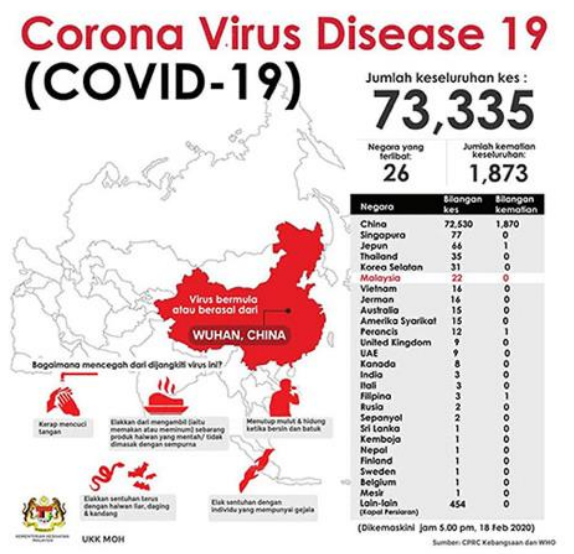

Figure 1 Statistics of Covid-19 disease. Retrieved August 12, 2020, from https://moh.gov.my.

The second component is 'What was said'. In visual communication, visual content plays in important role deliver a message to target audience. Visual content will represent 'what was said' to send message in detail of Covid-19 disease. During the MCO situation, MOH and NSC attempted to spread all information about pandemic Covid-19. Figure 2 shows an example of a visual guideline wearing a mask. This visual content is from $\mathrm{MOH}$ showing the right way of using and how to keep the masks during the eating activities.

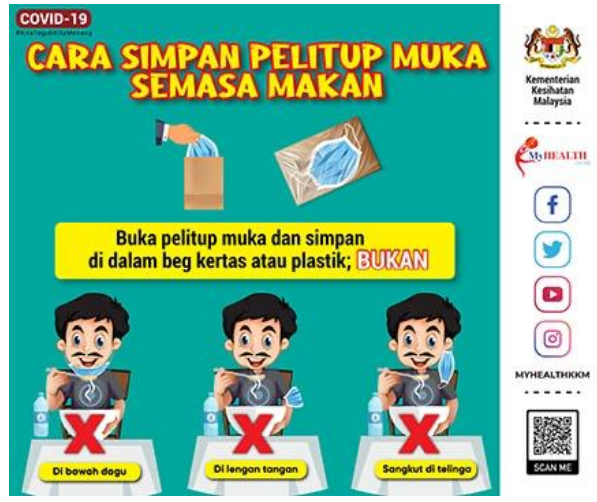

Figure 2 Wearing a mask. Retrieved August 8, 2020, from https://moh.gov.my.

The third component is 'In what channel it was said', would describe the right channel that's available and suitable to use by $\mathrm{MOH}$ dan NSC sending message, guidelines and SOP to the target audience. It is an important aspect because the right channel will help $\mathrm{MOH}$ and NSC efficiently prevent spreading the disease of pandemic Covid-19. Social media usage increase in digital and online activities and most people around the world using digital and online activities to get information about pandemic Covid-19 [15]. Figure 3 
show an example of channel used during the pandemic Covid-19.

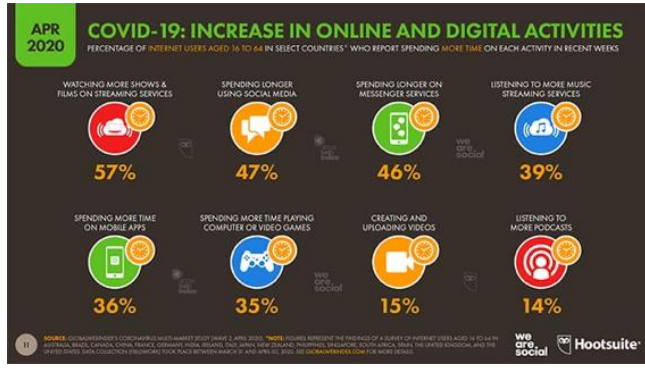

Figure 3 Online and digital activities. Retrieved August 10, 2020, from https://www.datareportal.com.

The fourth component is 'To whom it was said', can be refer to target audience. Appropriate visuals are used to convey intent to all age ranks and walks of life. Different visual uses are aimed at the target audience so that message understanding can be well received. When a message is well received to the target audience, it proves that the visual communication achieves its objectives and success is achieved. As an example, on figure 4 a visual communication of a guideline for Muslim prayers in Malaysia were given to will make sure all Muslim prayer follow the SOP by NSC when they're entering a Mosque.

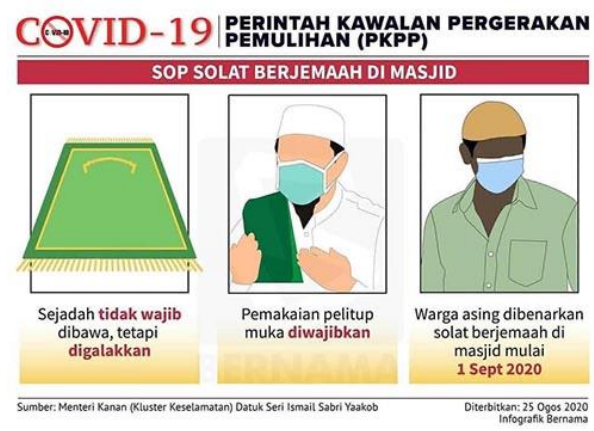

Figure 4 Target audience, all Malaysian Muslim. Source from Infographic Bernama

The fifth component is 'What effect it was said', refer to acceptance and understanding of target audience against visual presentation of Covid-19 disease. Whether it is well receivable or otherwise. Accurate use of visuals affects the objectives to be delivered. In figure 5 shows a simple visual example to understand. The World Water Day, WHO describes a step-by-step visual guideline how to wash hand regularly with soap or by an alcohol-based hand rub.

\section{How to Handwash?}

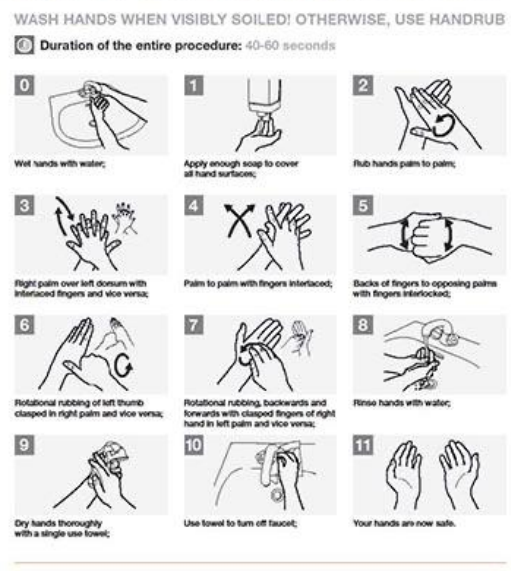

Clean hands are life savers

Figure 5 Guideline washing hand. Source from Queensland Urban Utilities

Pandemic Covid-19 has already becomes a worldwide problem, given a bad impact and disaster to all over the world. Due to this situation, all of the communication activities affected. Messages and information were delivered and received by an electronic method. Everyone start began thinking about appropriate communication methods and strategies to deliver messages. During the pandemic Covid-19, communication strategy becomes an important factor in order to make sure that all of health message and information can be delivered as effective as it could to the communities. Using and planning the right channel or platform of communication media, will affect and help to develop the ability of the awareness target audience through their level knowledge on health needs [6]. It had overcome the knowledge of health awareness that it is so important to stay and always keep healthy all the time. Knowledge of health awareness will help prevent the national health problem such as drug issues.

Although visual communication is found to be an important element when presenting the message during Covid-19, the understanding and acceptance of target audiences against visual presentation is also an important factor to be considered. Visual usage needs to be appropriate and coincided with the appropriate channels and platforms. Each target audience has a varied perception of the accepted message. Not all target audience have the same understanding, will and needs. Each has a varied level of knowledge about visual communication. Target audience's acceptance of information and messages differs according to current desires, experiences and knowledge [13]. It is this difference that affects the target audience about how the message is delivered and whether the channel used corresponds to the target audience. 
Visual communication is an important aspect during the pandemic Covid-19 and it should also be recognized as a front liner. The visual role of communication is just as important as health and safety front liners during the pandemic Covid-19. The use of various forms and elements of communication, including the integration of media and communication technology when communicating helps a lot in creating efficient and effective communication [9]. A study was conducted by [12] on the visual importance of communication on social media, stated that social media plays an effective role in advertising a product brand. Visual and product overview can be presented more effectively to the communities. The research on product advertising through social media found that social media promotion has a close and positive relationship with the communities. This means that the strategy of selecting communication channels through social media can be accepted by the communities. It is found to be very suitable and able to realize effectiveness in communication to the communities. Advertising can run more effectively, quickly and easily.

During the enforcement of MCO on pandemic Covid19 , communication is communicated through various communication channels. In addition to the health fact message of Covid-19 disease delivered through oral and text, visual representation also plays a very important role in conveying information to the communities. Communication channel example, such as infographics, charts, illustration, advertisement and photographs as well as internet and social media networks through Google, Yahoo, YouTube Videos, E-mails, Instagram, Facebook, Twitters, WhatsApp and Telegrams.

The implementation and usage of visual content on Covid-19 disease during the pandemic quickly helps a lot to increase understandability of health instructions and SOP is given by the MOH. With the help and contribution from Non-Government Organization (NGO) this organization from time to time put their full effort delivery health messages and instructions regarding the SOP to the communities in order to send information about Covid-19. At once, early of knowing the Covid-19 disease, many of people is getting hard to understand more about the disease, what is the best way of prevention it?, the guidelines that everyone should follows and everything about the pandemic issues. This situation happened because all of people were afraid and this pandemic Covid-19 effect on their daily lifestyle, family activities, family economy, country and all the society over around the world. Health information and guidelines through the website Malaysian Ministry of Health [5], Covid-19 was created to share health information, messages and SOP of pandemic Covid-19. In this website, all knowledge of the guidelines, information and infographic were provided to the target audience of Malaysian such as the guidelines and SOP of social distancing, how to wear a mask, washing hands, movement control order and lots more. Visual content representation of Covid-19 disease was used as a way to deliver messages to target audience. An example in Figure 6 shows that visual illustration of wearing a mask to the target audience. An illustration of a woman was used through this message to deliver step by step process on how to wear a mask correctly.

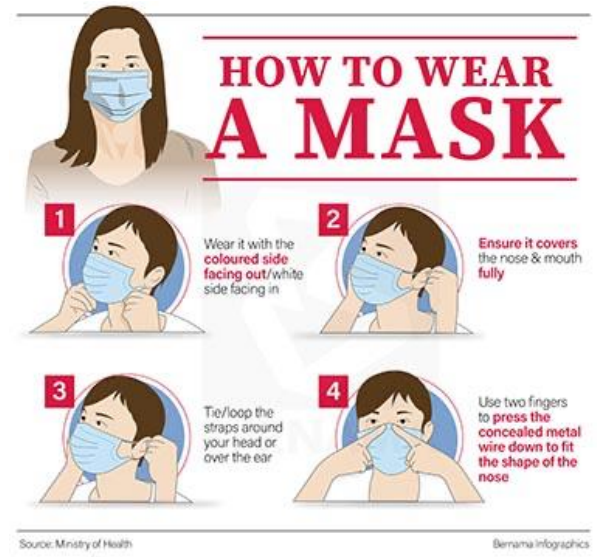

Figure 6 Guideline wearing a mask. Retrieved August 10, 2020, from https://www.pmo.gov.my.

World Health Organization (WHO) is a very recognized body worldwide. In an article on its website, there is a importance of visual roles towards health messages to the communities. The use of visual messages is very helpful in delivering information by WHO [7]. It is easier to understand and effectively achieve target audience of different ages, backgrounds and education levels. Videos and images helps to enhance storytelling and describes how WHO's work sharing messages and information to target audience. WHO reports visual presentation is easier way to deliver messages other than delivery it through text. Visual presentation is easy to deliver to target audience by:

- Visual by illustrations and images represent the technical information so that it is easier to understand.

- Using visual on drawing to show the process steps by steps. It will clarify sequences, connections and the relationships.

- Images and graphics as a visual content in social media. Health visual presentation in social media will encourage target audience to share those messages with their social media networks, follower or friends.

Figure 7 shows an example of infographic by WHO. This infographic uses visual illustration in delivering important messages to the target audience. This visual communication using six different visual of illustration presented along with the text information to describe how 
to protect yourself, reduce the risk of Covid-19 in the daily life activities. Diverse colors are also used to appeal to the target audience.

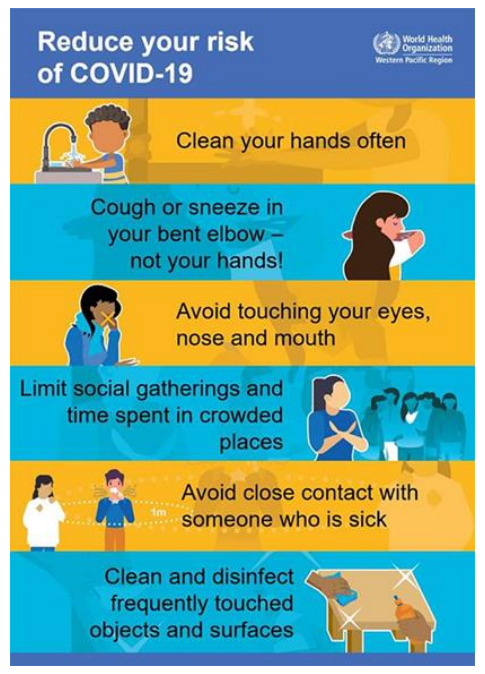

Figure 7 Guideline to reduce risk of Covid-19. Source from World Health Organization (WHO).

\section{IMPORTANT ROLE OF VISUAL COMMUNICATION}

Visual communication is a process of delivery of information involving visuals. It is communicated through a combination of photography, animation, illustration, typography, symbol/emblem, advertising, multimedia and even graphic images. In line with the current digital information, visual communication becomes a necessity and important to all world societies. Having a tremendous health scare and statistic record stated that more than a thousand of deaths around the world, this pandemic Covid-19 has received fully wide media coverage since it was discovered last year.

Various sectors of the industry use visual communication methods to communicate information and disseminate information to the communities. During the pandemic Covid-19 where the use of visual communication methods is used comprehensively around the world. Various SOP guideline requirements are issued by the Malaysian government on Covid-19 publicizing guidelines to the communities on how to curb, treat and control Covid-19 disease. As a factor not to cause panic among all communities, several SOPs have been introduced and implemented. Visual communication plays an important role in the government's recommended SOP implementation. The question is, does visual communication seek to impact and educate the communities about SOP information in the Covid-19 regulatory aspects suggested by the Malaysian ministry of health?. What is the community's perception and understanding of Covid-19 information through visual communication presented?
During the early of pandemic Covid-19, most of the people on earth haven't actually seen how and do not know what is Coronavirus/ Covid-19 looks like. Everybody was wondering how dangerous and how bad Covid-19 effects is. Visual graphic images of the Covid19 virus have been introduced, explained and publicized to the public to describe that this is the appearance of the Corona virus or known as the Covid-19. The National Institute of Allergy and Infectious Diseases' (NIAID) Rocky Mountains Laboratories (RML) [1], have just released scanning and transmission electron microscope images of the coronavirus and they're surprisingly aesthetically pleasing.

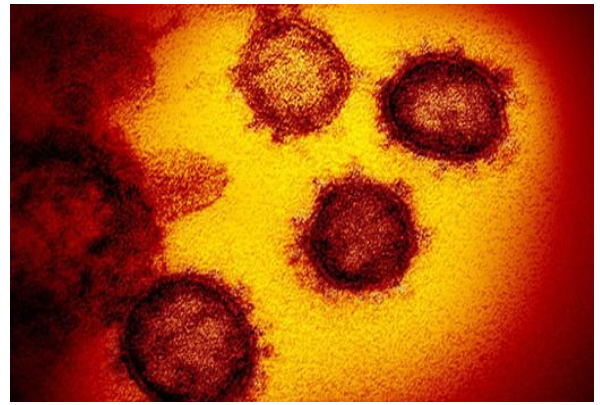

Figure 8 Visual Corona Virus/Covid-19. Retrieved August 5, 2020, from https://www.niaid.nih.gov

The announcement of the Covid-19 virus form was first introduced with various shapes. The appearance of the Covid-19 virus began to be enhanced in the appearance of diverse graphic shapes such as logos, illustrations began to flood print media spaces and electronic media. The graphic image was designed based on the original Covid-19 visual which was intended to be more recognizable and easier to explain to the communities about the virus. Figure 9 shows symbols, emblems and red colors used as graphic images to describe disease Covid-19. The graphic image was designed based on the original Covid-19 visual which was intended to be more recognizable and easier to explain to the communities about the virus.
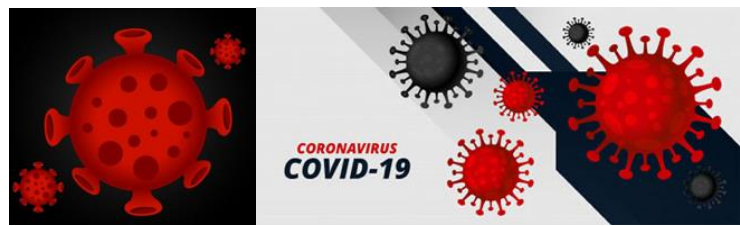

Figure 9 Graphic image of Corona Virus/Covid-19. Retrieved August 16, 2020, from https://www.freepik.com

\section{VISUAL COMMUNCATION IS THE ROLE OF EDUCATING}

Illustrations, graphic images, logos and graphic info began to visual content through print media platforms and mass media. Television, newspapers, magazines, 
social media and posters is publicized solely to teach communities what to do and what not to do. Currently, the importance of visual communication towards all levels of society, regardless of young or old is disclosed with visual information so that the communities can understand all the SOPs that must be observed timely and in every place. For example, visual graphic info on how a proper use of face masks for various ages. It is as shown in Figure 10. Not only government departments, but NGOs also helped out the guidelines in order to educate the communities about Covid-19 information that needs to be known.

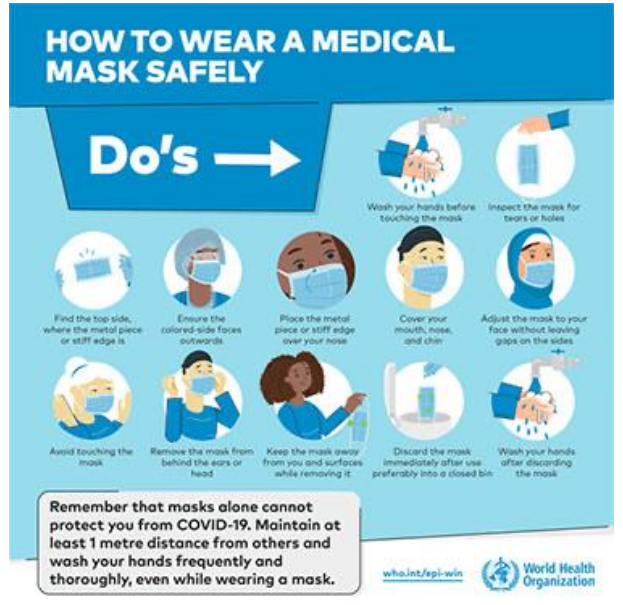

Figure 10 Infographic on wearing a mask. Source from World Health Organization (WHO).

\section{VISUAL COMMUNCATION SERVES TO FACILITATE UNDERSTANDING}

As long as the pandemic Covid 19 hasn't ended, the communities needs to be disclosed with current information. The understanding of visuals helps to reduce the stress of people in living their daily lives and days to be aquired. When there is a need and the resolution of the communities to sit at home (during the MCO) the communities needs to understand what SOPs should be observed. Information should reach the public accurately and as quickly as possible. Hence, visual communication plays an important role to help effectively channel information.

Visual communication, especially during pandemic Covid-19 is able to accelerate the understanding of what the $\mathrm{MOH}$ and the NSC wants to deliver. Figure 11 shows examples of visual interests in helping to communicate more effectively to facilitate public understanding of compliance and guidance when carrying out daily life. The visuals on display are very easy to understand which means explaining the need for social distancing should be practiced.

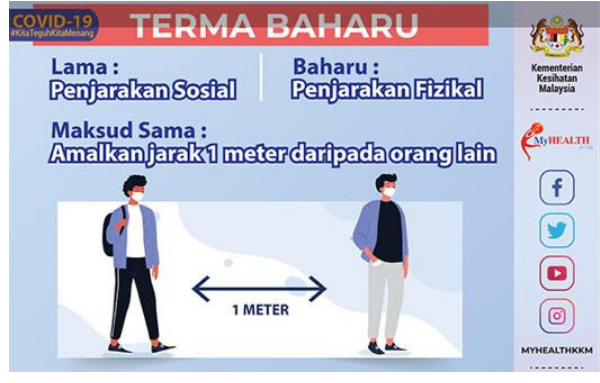

Figure 11 Communication on social distancing.

Retrieved August 28, 2020, from https://moh.gov.my

Figure 12 shows a programs of hygiene and social distancing practices if they are nervous. The visuals shown are intended to make it easier for people to understand faster and clearer. The visual layout gives a clear picture of the actual situations that need to be practiced during the pandemic Covid-19. It is easy to understand by all ages.

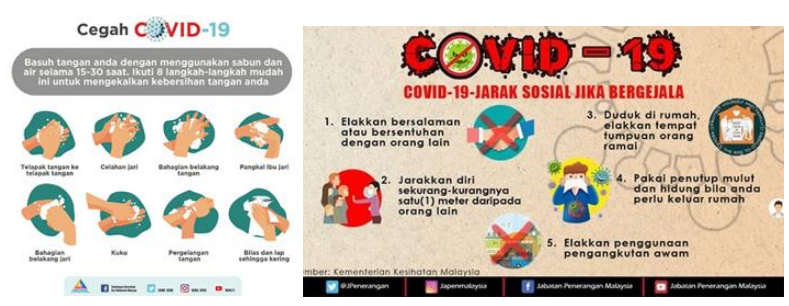

Figure 12 Infographic of hygiene practices and social distancing. Source from Jabatan Penerangan Malaysia.

\section{CONCLUSION}

This conceptual paper describes and discuss the important of visual as a communication media during the pandemic Covid-19. In conclusion the pandemic Covid19 has given a contingency blow to the rest of the country. It gives a great challenge to the aspect of communication. As each country struggles to combat the pandemic Covid-19, the aspect of communication becomes the most important element for each individual in every situation, every time and every place. Communities are plagued by confusion with this situation. Hence, visual communication plays an important role in helping to communicate important information about pandemic Covid-19. Serious attention should be taken into the aspect of visual communication so that it is able to provide an effective role. There is no denying that visual communication is also the most important contributor to the control of the pandemic Covid-19 in addition to the recognition and sacrifice of fronliners such as the MOH and the NSC.

\section{AUTHORS' CONTRIBUTIONS}

DR HANAFI MOHD TAHIR is currently a senior lecturer at Graphic \& Digital Media, Faculty of Art \& Design, Universiti Teknologi MARA (UiTM). He 
completed his $\mathrm{PhD}$ at Universiti Kebangsaan Malaysia in Communication. His area of research covers Visual Communication, Advertising, Corporate Identity. He can be contacted at hanaf185@uitm.edu.my

DR NAGIB PADIL is currently a senior lecturer at Photography \& Creative Imaging, Faculty of Art \& Design, Universiti Teknologi MARA (UiTM). He is also Programme Coordinator of Photography \& Creative Imaging Department. He completed his $\mathrm{PhD}$ at Universiti Teknologi MARA (UiTM) in Art \& Design. His area of research covers Photography, Creative Imaging. He can be contacted at nagib746@uitm.edu.my

MR. MOHD SHAHRIL ABD RASHID is currently a senior lecturer at Graphic \& Digital Media, Faculty of Art \& Design, Universiti Teknologi MARA (UiTM). He is currently a PhD student at Universiti Kebangsaan Malaysia. His area of research covers Advertising, Branding. He can be contacted at mohd370@uitm.edu.my

DR. SHAHREL NIZAR BAHAROM is currently a senior lecturer at Graphic \& Digital Media, Faculty of Art \& Design, Universiti Teknologi MARA (UiTM). He is also Programme Coordinator of Graphic \& Digital Media Department. His area of research covers New Media, Gaming. He can be contacted at shahr169@uitm.edu.my

DALILA KAMARUDIN is currently a Head of Graphic, MPH Group Printing Sdn. Bhd. Her current work focuses on book publishing and graphic design. She had a wide graphic knowledge with 13 years of experience in related fields. She can be contacted at delila.dali@gmail.com

\section{REFERENCES}

[1] Amanda, K. (2020). This is what the deadly coronavirus looks like under microscope. DOI: https://www.cnet.com/news/this-is-what-thedeadly-coronavirus-look-like-under-a-microscope.

[2] Berita Harian Online (2020). Kronologi COVID-19 di Malaysia. DOI: http://www.bharian.com.my/berita/nasional/2020/0 3/666122/kronologi-covid-19-di-malaysia.

[3] David, C, \& Paul, H. (2016). Communication in history: Technology, Culture, Society. Routledge Pearson, Education Inc, New York. USA.

[4] Faridah Ibrahim, Tika Nuraeni, Fauziah Ahmad, Chang Peng Kee \& Normah Mustaffa (2012). Bahasa komunikasi visual dan pengantaraan produk: Satu analisis semiotik. GEMA Online Journal of Language Studies 257, Volume 12(1), January 2012.

[5] Garis Panduan KKM: Covid-19 Malaysia. DOI: http://covid-19.moh.gov.my/infografik
[6] Mohamad Hafifi Jamri, Nurzali Ismail, Jamilah Ahmad, \& Darshan Singh. (2017). Kempen kesedaran kesihatan awam: Satu tinjauan literatur dari sudut penggunaan media dan komunikasi di Malaysia. Jurnal Komunikasi: Malaysian Journal of Communication, 33(3), pp 1-20.

[7] Make it visual: Tactics to apply to make your communications understandable. DOI: https://www.who.int/about/communications/unders tandable/visuals.

[8] Maizatul Haizan Mahbob, Nik Anis Syakira Megat Ali, Wan Idros Wan Sulaiman. (2019). Komunikasi strategik dan peranannya untuk mewujudkan komunikasi berkesan dalam organisasi. Jurnal Komunikasi: Malaysian Journal of Communication, 35(2) 2019, pp 49-67.

[9] Nur Idayu Yusri (2017). Pelaksanaan literasi visual dalam pengajaran dan pembelajaran. Pendeta Jurnal of Malay Language, Education and Literature, Jilid 8, 2017 / ISSN 1823 - 6812, pp 66-71. DOI: ejournal.upsi.edu.my

[10] Peter, F. D. (2017). Hieroglyph: Writing character. DOI:

https://www.britannica.com/topic/hieroglyphicwriting.

[11] Peng, W. (2015), Analysis of New Media Communication Based on Lasswell's " 5 W" Model. Journal of Educational and Social Research. Vol. 5 No.3. MCSER Publishing, Rome-Italy.

[12] Raji Ridwan Adetuji, Sabrina Mohd Rashid, \& Mohd Sobhi Ishak. (2018). Social media marketing communication and consumer-based brand equity: An account of automative brands in Malaysia. Jurnal Komunikasi: Malaysian Journal of Communication, 34(1), pp 1-19.

[13] Rosli Mohammed. (2015). Strategi pengurusan komunikasi dalam membangun masyarakat nelayan. Sintok: Pusat Pengajian Teknologi Multimedia dan Komunikasi, Universiti Utara Malaysia.

[14] Syerif Nurhakim (2015), Dunia komunikasi dan gadget: Evolusi alat komunikasi, menjelajah jarak dengan gadget. Penerbit Bestari, Jl. Waru, Jakarta.

[15] Simon, K. (2015), Digital 2020: July global statshot. DOI: https://datareportal.com/reports/digital-2020-julyglobal-statshot. 